\title{
Analisis penerapan strategi pembelajaran ekspositori terhadap prestasi belajar fisika ditinjau dari gaya belajar siswa
}

\author{
Novi Ayu Kristiana Dewi \\ STMIK Pringsewu, Lampung \\ Jl. Wisma Rini No.9, Pringsewu Sel 35373 Lampung, Indonesia \\ Surat-e: noviayudi@gmail.com \\ Riswanto \\ Universitas Muhammadiyah Metro, Lampung \\ Jl. Ki Hajar Dewantara, No. 116, Kota Metro, Lampung \\ Surat-e: rumbiariswan@gmail.com
}

\begin{abstract}
Penelitian ini bertujuan untuk menggambarkan dan mengungkapkan pembelajaran ekspositori terhadap prestasi belajar fisika siswa ditinjau dari gaya belajar. Jenis penelitian ini adalah deskriptif kualitatif dengan memaparkan, menuliskan, dan melaporkan keadaan suatu objek atau peristiwa apa adanya. Data dalam penelitian diperoleh melalui kuisioner, observasi, wawancara, dokumentasi, dan pustaka yang selanjutnya dilakukan triangulasi. Teknik analisis data yang digunakan adalah menurut Miles dan Hubermen, yaitu: reduksi data, penyajian, dan penarikan kesimpulan. Hasil penelitian menunjukkan bahwa strategi pemebelajaran ekspositori yang diterapkan dalam pemebelajaran fisika yang terdiri dari siswa dengan gaya belajar heterogen, yaitu: visual sebanyak 28,33\% siswa, auditorial sebanyak $35 \%$ siswa, dan kinestetik sebanyak 36,67 \% dinyatakan tidak berhasil karena hanya 3,33\% siswa yang tuntas belajar.
\end{abstract}

This study aims to describe and explore the expository learning on physics learning achievement reviewed of students' learning styles. This type of research is descriptive qualitative by describing, writing, and reporting the state of an object or event as it is. The data in the study were obtained through questionnaires, observations, interviews, documentation, and literature review which were then triangulated. The data analysis technique have used Miles and Hubermen, namely: data reduction, presentation, and conclusion. The results showed that expository learning strategies applied in physics learning consisted of students with heterogeneous learning styles, namely: visual as much as $28.33 \%$ students, auditory as much as $35 \%$ students, and kinesthetic as much as $36.67 \%$ were declared unsuccessful because only $3.3 \%$ of students have completed learning.

Kata kunci: strategi pembelajaran ekspositori, pretasi belajar, dan gaya belajar

\section{Pendahuluan}

Belajar merupakan suatu proses yang disengaja dan secara sadar dilakukan untuk mencapai tujuan pembelajaran yang telah ditetapkan melalui latihan dan pengalaman sehingga terjadi perubahan yang lebih baik. Belajar dan pembelajaran merupakan kegiatan utama dalam setiap penyelenggaran jenjang pendidikan. Tanpa adanya kegiatan belajar dan pembelajaran maka tidak ada proses pendidikan. Salah satu jenjang pendidikan formal tempat para siswa dan guru melakukan kegiatan belajar dan pemebelajaran adalah Sekolah Menengah Atas (SMA).

Berhasil atau gagalnya tujuan pembelajaran di sekolah sangat bergantung dari proses pembelajaran yang diberikan oleh guru, sehingga mutlak adanya guru sebagai pengendali dari kegiatan pembelajaran dan partner bagi siswa. Tanpa adanya pengendalian dari guru maka proses pembelajaran tidak dapat berjalan baik, bahkan tujuan dari pembelajaran pun tidak akan terarah. Oleh karena itu, guru harus mampu menguasai kelas untuk menciptakan pembelajaran yang kondusif, memberi motivasi, latihan, kesempatan, dan penilaian untuk mengetahui tingkat keberhasilan siswa. Dan pembelajaran seharusnya dapat dilakukan dengan memaksimalkan seluruh potensi siswa serta sarana dan prasarana yang tersedia terutama pemanfaatan laboratorium dalam pembelajaran fisika sehingga pembelajaran fisika akan lebih menarik [1]. Selanjutnya menurut Trianto [2] bahwa dalam proses pembelajaran dapat dioptimalkan dengan strategi pembelajran yang dimplementasikan sesuai dengan kebutuhan dan keadaan siswa maupun sekolah. Sedangkan pemilihan strategi 
pembelajaran disesuaikan dengan gaya belajar siswa di kelas [3]. Dengan demikin jelas bahwa dalam penerapan strategi pembelajaran guru harus memperhatikan aspekaspek yang ada pada siswa, salah satunya adalah gaya belajar, karena gaya belajar merupakan cara yang paling mudah atau disenangi oleh siswa untuk menerima pengetahuan sehingga apa yang disampaikan oleh guru menjadi bermakna dan tujuan pembeajaran mudah dicapai.

Prasurvei yang dilakukan di SMA Paramarta 1 Seputih Banyak pada kelas X bahwa ketuntasan belajar fisika masih jauh dari berhasil, hanya 44,74\% siswa yang tuntas, sedangkan keberhasilan proses pemebelajaran apabila $\geq 85 \%$ siswa dinyatakan tuntas. Artinya dalam proses pembelajaran tersebut tujuan belajar siswa pelum tercapi dengan optimal. Berdasarkan wawancara dengan guru mata pelajaran fiska bahwa ketidakberhasilan pembelajaran ini karena siswa yang kurang aktif mengikuti pembelajaran di kelas, sering mengobrol, tidak memperhatikan guru, dan tidak mengerjakan tugas. Sedangkan siswa yang mencapai nilai KKM atau ketuntasan belajar adalah siswa yang cerdas dan aktif dalam kegiatan pembelajaran. Dalam kegiatan pembalajran guru juga lebih sering menggunakan strategi pembelajaran langsung karena keterbatasan waktu dan keadaan siswa yang lebih banyak pasif.

Berdasarkan permasalahan tersebut bisa ditarik kesimpulan sementara bahwa ketidakaktifan siswa dalam proses pembelajaran bukan karena kemampuan siswa yang rendah terhadap fisika tetapi bisa disebabkan karena strategi pembelajaran yang diterapkan guru tidak sesuai dengan keadaan siswa di kelas. Oleh karena itu, perlu adanya penelitian untuk mengungkapkan dan menggambarkan strategi pembelajaran langsung atau ekspositori dalam pembelajaran fisika dan apakah strategi pembelajaran tersebut sudah sesuai dengan gaya belajar siswa di kelas.

\section{Kajian Pustaka}

Ref. [4] menyatakan bahwa strategi pembelajaran merupakan cara-cara yang akan dipilih oleh guru agar materi pembelajaran yang disampaikan ke siswa dapat diterima dan dipahami dengan baik sehingga tujuan pengajaran dapat dikuasai di akhir kegiatan belajar. Selanjutnya ref. [5] menyatakan bahwa strategi pembelajaran merupakan suatu siasat yang dilakukan oleh guru agar interaksi antara siswa dan komponen pembelajaran untuk mencapai tujuan pengajaran dapat berfungsi dengan optimal, efektif, dan efesien. Menurut ref. [3] ada beberapa jenis strategi pemebelajaran, yaitu:

1. Strategi pembelajaran langsung atau dikenal dengan strategi pembelajaran ekspositori yaitu startegi pembelajaran yang perpusat pada guru dengan menekankan proses penyampaian materi secara verbal agar siswa dapat menguasai materi secara optimal. Langkah-langkah yang dilakukan dalam penerapan strategi ekspositori antara lain: persiapan, penyajian, menghubungkan, menyimpulkan, dan menerapkan.

2. Strategi pembelajaran tidak langsung yaitu strategi pembelajaran yang berpusat pada siswa dan tugas guru hanya sebagai fasilitator. Ada beberapa jenis strategi pembelajaran tidak langsung, antara lain:

a) Inkuri, yaitu strategi pembelajaran yang menuntut siswa aktif menemukan jawaban dari suatu permasalahan melalui proses tanya jawab. Masalah yang dipecahkan dalam strategi pembelajaran inkuiri bersifat tertutup, artinya jawaban sudah diketahui oleh guru namun tidak langsung disampaikan kepada siswa. Adapun langkah-langkah strategi pembelajaran inkuiri adalah: observasi, perumuskan masalah, pengajuan hipotesis, pengumpulkan data, pengujian hipotesis, dan penarikan kesimpulan.

b) Strategi pembelajaran berbasis masalah, yaitu strategi pembelajaran yang menekankan pada proses penyelesaian masalah secara ilmiah. Masalah yang dipecahkan dalam strategi pembelajaran ini bersifat terbuka, artinya siswa dan guru dapat mengembangkan kemungkinan jawaban. Adapun langkah-langkahnya: menyadari masalah, merumuskan masalah, merumuskan hipotesis, dan menentukan pilihan penyelesaian.

c) Strategi pembelajaran kontekstual, yaitu strategi pembelajaran yang melibatkan siswa secara penuh dalam pembelajaran dan guru membantu siswa membuat hubungan antara pengetahuan yang diperoleh dengan kehidupan nyata. Adapun langkah-langkahnya: pendahuluan, kegiatan inti di kelas dan lapangan, dan penutup.

d) Strategi pembelajaran interaktif atau yang dikenal dengan strategi pembelajaran kooperatif, yaitu strategi pembelajaran yang menekankan pada diskusi dan sharing sehingga memberikan kesempatan pada peserat didik untuk memberikan gagasan dan pengalaman. Adapun langkahlangkahnya: penjelasan materi, belajar kelompok, penilaian, dan pengakuan tim.

e) Strategi pembelajaran empirik adalah strategi pembelajaran yang perpusat pada peseta didik dan berbasis aktivitas melalui kemampuan telaah fakta-fakta atau pengalaman siswa sebagai bahan pemecahan masalah.

f) Strategi pembelajaran mandiri adalah strategi pembelajaraan yang bertujuan membangun kemandirian siswa dengan bantuan guru

g) Strategi pembelajaran efektif yaitu strategi pembelajaran yang dapat menumbuhkan sikap kesadaran karena refeksi dari dalam diri. 
Pemilihan strategi pembelajaran akan menentukan proses pembelajaran dalam mencapai tujuan belajar. Ada banyak faktor yang harus diperhatikan sebelum memilih strategi pembelajaran, salah satunya adalah keadaan siswa yaitu keadaan gaya belajar yang dimiliki oleh siswa di kelas. Menurut Sternberg dalam ref. [6] bahwa gaya belajar bukanlah kemampuan yang ada di dalam diri individu melainkan suatau cara yang mampu untuk digunakan. Gaya belajar merupakan cara yang paling dominan dan selaras yang dimiliki oleh siswa sebagai modalitas belajar berdasarkan cara kerja otak untuk menyerap, memproses, dan memepertahankan informasi dan keterampilan yang ada. Ref. [7] menyatakan bahwa berdasarkan kemampuan otak gaya belajar dibagi menjadi tiga kategori, yaitu: visual, auditorial, dan kinestetik. Ref [8] menyatakan bahwa siswa dengan gaya belajar visual cenderung menerima informasi paling baik dan efektif dengan memakai indra penglihatannya, peseta didik dengan gaya belajar auditorial cenderung menerima informasi paling baik dan efektif dengan memanfaatkan pendengarannya, dan siswa dengan gaya belajar kinestetik cenderung menerima informasi paling baik dan efektif dengan melibatkan gerakan tubuh, pengalaman gerak tubuh, atau perasaan dan akan lebih suka belajar apabila ikut terlibat langsung pada permasalahan yang sesungguhnya.

Penelitian [9] membuktikan bahwa ada interaksi antara startegi pembelajaran dan gaya belajar terhadap prestasi belajar fiska. Namun pada penelitian [10] bahwa gaya belajar tidak berpengaruh terhadap prestasi belajar. Berdasarkan dua penelitian tersebuat dapat disimpulkan bahwa keberhasilan dari proses pembelajaran tidak ditentukan oleh gaya belajar siswa, namun keberhasilan proses pembelajaran ditentukan dari strategi pembelajaran yang diterapkan oleh guru dengan memperhatikan gaya belajar siswa di kelas.

\section{Metode Penelitian}

Jenis penelitian ini adalah deskriptif kualitatif dengan memaparkan, menuliskan, dan melaporkan keadaan suatu objek atau peristiwa apa adanya. Kehadiran peneliti di lapangan bukan untuk melakukan eksperimen tetapi sebagai pengamat penuh untuk mengumpulkan data berupa fakta-fakta melalui kuisioner, wawancara, observasi, dokumentasi, dan pustaka yang kemudian dilakukan triangulasi.

Penelitian ini dilakukan pada pembelajaran fisika materi listrik dinamis selama tiga pertemuan pada kelas $\mathrm{X}$ SMA Paramarta 1 Seputih banyak yang terdiri dari tiga kelas dengan total 76 siswa. Namun untuk mencapai tujuan penelitian secara efektif maka responden yang digunakan dalam penelitian ini hanya siswa yang tidak pernah absen selama 3 pertemuan tersebut, sehingga hanya ada 60 siswa.

Kuisioner dalam penelitian ini digunakan untuk mengetahui gaya belajar yang dimiliki oleh siswa yaitu dengan mengadopsi kuisioner Gaya Belajar Individu (VAK Learning Test) [8]. Observasi digunakan untuk memperoleh data tentang penerapan strategi pembelajaran ekspositori serta aktivitas siswa dan guru selama kegiatan pembelajaran dalam bentuk catatan di lapangan. Dokumentasi dalam penelitian ini digunakan untuk memperoleh arsip hasil belajar fisika setelah kegiatan pembelajaran pada materi listrik dinamis selesai dan arsip RPP yang dimiliki guru. Wawancara digunakan untuk mengetahui informasi yang dibutuhkan dalam penelitian terhadap informan terutama guru. Pustaka digunakan untuk mengumpulkan teori dan fakta-fakta hasil penelitian yang menunjang tujuan penelitian. Dan untuk mengetahui keakuratan data maka dilakukan triangulasi.

Teknik analisis data yang digunakan adalah teknik analisis data menurut Miles and Hubermen. Langkahlangkah yang dilakukan dalam keknik analisi ini adalah:

1. Reduksi data, yaitu dengan memilah data yang penting, melakukan pengelompokan data berdasarkan kategorinya, dan membuat ringkasan. Dalam tahap ini menentukan responden yang digunakan dalam penelitian, yaitu siswa di kelas $\mathrm{X}$ yang tidak pernah absen selama kegitan pembelajaran satu pokok bahasan sampai penilaian hasil belajar. Selanjutnya mengelompokkan data siswa berdasarkan gaya belajarnya dan mengelompokkan perolehan hasil belajar kedalam kategori tinggi, rendah, sedang, serta tuntas dan tidak tuntas dalam belajar. Membuat catatan pengamatan selama kegitan pembelajaran berlangsung untuk mengamati penenerapan strategi pembelajaran ekspositori.

2. Penyajian data, yaitu menyajikan data hasil penelitian dalam bentuk teks narasi dan tabel sehingga mudah dipahami.

Penarikan kesipulan merupakan hasil analisis sehingga ditemukan hubungan antar variable untuk menjawab permasalah penelitian. Dengan demikian dapat diketahui tentang gambaran penerapan strategi pembelajaran ekspositori pada kelas yang terdiri dari siswa dengan berbagai gaya belajar.

\section{Hasil Penelitian dan Pembahasan}

Langkah pertama sebelum pengamatan di kelas dilakuakan adalah dikumpulkannya data gaya belajar melalui kuisioner agar bisa dicocokkan dengan aktivitas siswa di kelas. Hasil kuisioner gaya belajar individu dalam penelitian ini mununjukan bahwa siswa kelas $\mathrm{X}$ SMA Paramarta 1 Seputih Banyak memiliki gaya belajar yang bervariasi, yaitu dari 60 siswa terdiri dari 28,33\% memiliki gaya belajar visual, $35 \%$ memiliki gaya belajar auditorial, dan 36,67\% memiliki gaya belajar kinestik. Artinya dalam temuan ini ternyata gaya belajar kinestetik adalah yang paling mendominasi dari gaya belajar lainnya, selanjutnya gaya belajar auditorial, dan terakhir gaya belajar visual. Data tentang gaya belajar siswa dapat dilihat pada tabel 1 di bawah ini. 
Tabel 1. Rekapitulasi Gaya belajar

\begin{tabular}{clcc}
\hline No & Gaya Belajar & Jumlah & \% \\
\hline 1 & Visual & 17 & 28,33 \\
2 & Auditorial & 21 & 35,00 \\
3 & Kinestetik & 22 & 36,67 \\
\hline & Jumlah & $\mathbf{6 0}$ & $\mathbf{1 0 0}$ \\
\hline
\end{tabular}

Selain melalui angket, gaya belajar peserta didik juga dapat teramati saat kegiatan pembelajaran, seperti siswa dengan gaya belajar visual mereka lebih suka memperhatikan guru saat pembelajaran dengan kegiatan mencatat, menggunakan spidol warna-warni untuk menandai materi pada buku pelajaran, dan siswa dengan gaya belajar visual terlihat lebih rapi dalam berbakain, lebih suka mengerjakan soal dalam bentuk tulisan. Selanjutnya siswa dengan gaya belajar auditorial lebih suka mendengarkan ulasan materi yang disampaikan oleh guru dan lebih suka menanggapi pertanyaan lisan yang singkat. Sedangkan pelajar kinestetik tidak bisa tenang seperti pelajar visual, pelajar kinestetik lebih suka menggerakkan anggota badannya saat belajar sehingga dianggap oleh guru tidak serius dalam pembelajaran.

Adapun strategi pembelajaran ekspositori yang diterapkan guru dalam proses pembelajaran yang berlangsung dalam pokok bahasan listrik dinamis sebagai berikut:

1. Pertemuan pertama dengan indikator mengenal alatalat ukur listrik, membedakan arus listrik AC dan DC, menunjukkan penerapan arus listrik AC dan DC dalam kehidupan sehari-hari. Langkah-langkah pembelajaran: 1) Persiapan, guru mengawali pelajaran fisika dengan menyampaikan topik materi yang akan disampaikan yaitu listrik dinamis, kemudian mengingatkan kembali kepada siswa tentang materi listrik statis ketika di SMP malaui tanya jawab. 2) Penyajian, guru menjelaskan materi yang ada di dalam buku pelajaran fisika yaitu tentang jenis-jenis alat ukur listrik dan manfaatnya, perbedaan sumber arus listrik AC dan DC serta pemanfaatannya dalam kehidupan sehari-hari, mejelaskan bagaimana arus elektron dan arus listrik dapat mengalir, menuliskan formula-formula tentang besaran listrik seperti kuat arus, beda potensial serta hukum Ohm beserta contoh dan penyelesaiannya di papan tulis. 3) Menghubungkan, guru menghubungkan antara materi yang telah disampaikan kepda siswa dengan soal-soal latihan tentang kuat arus, beda potensial, dan hukum Ohm untuk diselesaikan siswa dan memberikan kesempatan kepada siswa untuk mengerjakan soalsoal tersebut. 4) menyimpulkan, Di akhir pembelajaran guru memberikan tugas kepada siswa untuk dikerjakan di rumah dan guru menyimpulkan materi pembelajaran dengan menunjuk siswa untuk menjawab pertanyaan-pertanyaan lisan sebagai rangkuman dari materi yang telah disampaikan.

2. Pertemuan kedua denagn indikator menentukan kuat arus, tegangan, dan hambatan pada suatu rangkaian tertutup. Langkah-langkah pembelajaran: 1)
Persiapan, guru mengingatkan kembali tentang materi listrik dinamis yang telah disampaikan pada pertemuan sebelumnya. Membahas tugas yang telah diberikan kepada siswa pada pertemuan sebelumnya. 2) Penyajian, guru menyampaikan dan menjelaskan materi tentang komponen dalam rangkaian listrik serta menggambarkan jenis-jenis rangkaian dan menuliskan formula yang digunakan untuk menentukan nilai besaran-besaran listrik yang ada di dalamnya serta menjelaskan materi tentang arus listrik yang mengalir melalui titik percabangan pada hukum Kirchoff I beserta contoh dan penyelesaiannya. 3) Menghubungkan, guru memberikan beberapa permasalahan tentang rangkaian komponen listrik serta kuat arus yang melalui titik percabangan melalui gambar untuk diselesaikan sebagai latihan. 4) Menyimpulkan, guru menyimpulkan materi pembelajaran dengan menunjuk siswa untuk menjawab pertanyaan-pertanyaan lisan sebagai rangkuman dari materi yang telah disampaikan.

3. Pertemuan ketiga merupakan langkah selanjutnya pada strategi pembelajaran ekspositori dari pertemuan pertama dan kedua, yaitu langkah 5) Penerapan, penerapan yang dimaksud pada tahap ini adalah siswa dituntut untuk menerapkan pengetahuan yang telah diperolehnya selama kegitan pemebelajaran di kelas pada soal-soal ulangan harian untuk mengukur tingkat pencapain siswa.

Berdasarkan data hasil observasi bahwa benar guru menerapkan strategi pembelajaran ekspositori selama proses pembelajaran fisika. Selain melalui hasil pengamatan langsung, strategi pembelajaran ekspositori juga terlihat dari RPP yang digunakan oleh guru serta hasil wawancara langsung kepada guru bahwa strategi yang digunakan dalam pembelajaran adalah strategi langsung. Berdasarkan data hasil observasi selama proses pembelajaran dapat disimpulkan bahwa strategi pembelajaran ekspositori terdiri dari beberapa langkah, yaitu: persiapan, penyajian, menghubungkan, menyimpulkan, dan menerapkan. Selama kegiatan observasi ditemukan kelebihan dan kekurangan dari penerapan strategi pembelajaran ekspositori, kelebihannya guru dapat mengontrol keluasan materi yang harus dikuasai oleh siswa, sedangkan kekurangannya guru menyampaikan materi dengan mengggunakan metode ceramah sehingga peran aktif siswa dalam kegiatan pembelajaran tidak dapat dioptimalkan karena tidak melayani perbedaan gaya belajar siswa terutama pada pelajar kinestetik.

Alasan guru menerapkan startegi pembelajaran ekspositori adalah ketersedian waktu pembelajaran yang singkat sedangkan materi pelajaran cukup luas sehingga dengan strategi pembelajaran ekspositori guru dapat menegontrol keluasan materi yang dikuasai siswa, selain itu menurut guru mata pelajaran fisika karena keadaan siswa dengan berbagai karakter, tidak banyak yang memeiliki kemampuan di atas rata-rata, dan sedikitnya siswa yang sungguh-sunggu dalam belajar maka tidak memungkinkan dilakukan strategi pembelajaran yang 
berpusat pada siswa seperti kegiatan laboratorium atau lainnya. Padahal keadaan seperti ini justru menjadi tantangan guru untuk menciptakan pembelajaran yang menarik dengan melibatkan peran aktif setiap siswa, karena keaktifan siswa bisa dikontrol oleh guru selaku penegndali kelas. Oleh karena itu, perlu diperhatikannya pemilihan strategi pembelajaran agar setiap siswa terlibat aktif dalam kegiatan dan tidak lagi menganggap bahwa belajar fisika membosankan.

Hasil belajar siswa setelah mengikuti proses pembelajaran dengan strategi ekspositori menunjukkan ketuntasan belajar fisika hanya 3,3\% yaitu hanya 2 dari 60 siswa yang memperoleh nilai di atas KKM sebesar 65, kedua pelajar tersebut semuanya memiliki gaya belajara visual, sedangkan tidak ada siswa dengan gaya belajar auditorial dan kinestetik yang mencapai nilai KKM. Hal ini menunjukkan bahwa penerapan strategi pembelajaran ekspositori pada kelas dengan berbagai gaya belajar dikatakan belum berhasil, karena suatu pembelajaran dikatan berhasil apabila jumlah ketuntasan klasikal $\leq 85 \%$.

Selanjutnya perolehan hasil belajar fisika berdasarkan kategori tinggi, rendah, dan sedang yang terdiri dari 60 siswa: $3,33 \%$ mendapat nilai tinggi, $63,33 \%$ mendapat nilai sedang, dan 33,33\% mendapat nilai rendah. Dengan rincian hasil belajar tinggi didominasi oleh gaya pelajar visual sebesar $11,76 \%$, hasil belajar sedang didominasi oleh pelajar auditorial sebesar $66,67 \%$, dan hasil belajar rendah didominasi oleh pelajar kinestetik sebesar $36,36 \%$ dari total masing-masing gaya belajar. Sedangkan untuk rata-rata hasil belajar diperoleh: pelajar visual sebesar 48,82, pelajar auditorial sebesar 48,67, dan pelajar kinestetik sebesar 45,68.

Berdasarkan hasil penelitian tersebut, bahwa strategi pembelajaran ekspositori lebih cocok digunakan pada siswa dengan gaya belajar visual, karena gaya belajar visual lebih berpotensi untuk mendapatkan nilai yang lebih baik daripada dua gaya belajar yang lain.

Di dunia ini sebenarnya tidak ada satu gaya belajar yang lebih baik dari gaya belajar lainnya, setiap gaya belajar memiliki kelebihan dan kekurangan tersendiri. Oleh karena itu, dalam pemilihan strategi pembelajaran harus memeperhatikan kesesuaian dengan gaya belajar siswa. Pada penelitian ini kesesuain strategi pembelajaran ekspositori terhadap gaya belajar visual dapat diamati selama proses observasi yaitu ketika guru menjelaskan materi yang ada di buku, pelajar visual akan memeperhatikan penjelasan guru dengan menggarisbawahi bagian-bagian penting yang ada di buku dengan spidol warna-warni, pelajar auditorial akan memperhatikan dengan mendengarkan apa yang disampaikan oleh guru. Saat guru menjelaskan simbol, gambar, dan rumus-rumus fisika di depan kelas maka pelajar visual akan mencatat dengan detail dan rapi, namun pelajar auditorial lebih banyak mendengarkan dengan catatan yang kurang rapi atau tidak teratur. Ketika guru memeberikan contoh soal-soal fisika maka pelajar visual dapat mencatat contoh soal yang diberikan guru beserta penyelesaiannya kemudian memahaminya. Dan ketika guru menyimpulkan materi pelajaran, guru tidak memberikan kesempatan pada seluruh siswa di kelas melainkan dengan menunjuk salah satu siswa secara langsung, padahal dengan tanya jawab akan memberikan kesempatan pelajar auditorial untuk berperan aktif sehingga materi pelajaran yang telah diperoleh mudah diingat. Dari temuan hasil penelitian ini menunjukkan bahwa pada pembelajaran ekspositori guru hanya memfasilitasi gaya belajar visual tanpa memperhatikan kebutuhan gaya belajar auditorial atau kinestetik. Sehingga gaya belajar auditorial hanya sedikit terfasilitasi dan gaya belajar kinestetik sama sekali tidak terfasislitasi padahal persentase siswa dengan gaya belajar kinestetik adalah yang tertinggi. Hal ini berdampak pada prestasi atau perolehan hasil belajar siswa yang telah diuraikan di atas.

Berdasarkan hasil penelitian tersebut, maka setiap guru hendaknya mampu menerapkan strategi pembelajaran yang dapat memfasilitasis semua gaya belajar, sehingga siswa akan terlibat aktif dalam kegiatan belajar. Keaktifan siswa dalam kegiatan pembelajaran akan memberikan pengalaman bagi siswa sehingga akan menciptakan pembelajaran yang bermakna. Setiap gaya belajar berhak untuk terlibat aktif dalam kegiatan belajar dan memiliki kesamptan yang sama karena berdasarkan artikel pada ref. [6] dan penelitian [10] menunjukan tidak ada pengaruh antara gaya belajar dengan hasil belajar, hal ini menunjukkan bawa salah satu gaya belajar tidak lebih unggul dari gaya belajar lain. Kunci keberhasilan pembelajaran ada pada guru dalam memilih strategi pembelajaran yang mampu melibatkan keaktifan semua siswa di kelas. Dengan memahami gaya belajar siswa berarti membantu guru menentukan strategi yang akan digunakan dalam pembelajaran. Dan dalam kenyataan di lapangan pada penelitian ini bahwa gaya belajar dari siswa tidaklah seragam begitu juga pada temuan dalam ref. [11] bahwa dari 1000 siswa yang tersebar di beberapa negara memiliki kecenderungan gaya belajar visual sebanya $29 \%$, auditorial $34 \%$, dan kinestetik $37 \%$. Oleh karena itu, guru harus memilih strategi pembelajaran yang mampu memfasilitasi semua gaya belajar siswa, berarti strategi yang harus digunakan guru adalah strategi pembelajaran yang berpusat pada siswa. Karena berdasarkan penelitian [12] dan [13] ada pengaruh posistif dan signifikan secara bersama antara strtaegi pemebelajaran dan gaya belajar terhadap prestasi belajar.

Salah satu strategi pembelajaran yang berpusat pada siswa adalah strategi pembelajaran kontekstual berbasis REACT (Relating, Experiencing, Applying, Cooperating, and Transferring) menurut Crawford [14]. Dalam penelitian [15] bahwa strategi pembelajaran REACT mampu meningkatkan kecerdasan dan kreativitas peserat didik karena strategi tersebut melibatkan berbagai aktivitas seperti: membaca, menulis, menggambar, berdiskusi, presentasi, dan melakukan percobaan. Aktivitas-aktivitas tersebut memberikan peluang pada siswa dengan berbagai gaya belajar. Dan pada hasil penelitian lain [16] bahwa pembelajaran kontekstual dapat meningkatkan kemampuan koknitif siswa karena melibatkan keaktivan siswa untuk menemukan penegetahuan sendiri. 


\section{Kesimpulan}

Berdasarkan hasil penelitian dapat disimpulkan bahwa dari 60 siswa kelas X SMA Paramarta 1 terdapat tiga gaya belajar dengan rimcian sebagai berikut: $28,33 \%$ memiliki gaya belajar visual, $35 \%$ memiliki gaya belajar auditorial, dan 36,67 \% memiliki gaya belajar kinestetik. Penerapan strategi pembelajaran ekspositori dengan langkah-langkah: persiapan, peneyajian, menghubungkan, menyimpulkan, dan menerapkan pada siswa dengan gaya belajar yang beragam dinyatakan tidak berhasil karena guru tidak banyak memeberikan kesempatan pada siswa untuk terlibat aktif dalam kegiatan pembelajaran. Gaya belajar yang terfasislitasi dengan penerapan strategi pembelajaran hanyalah gaya belajar visual, kemudian auditorial, dan terakhir kinestetik padahal gaya belajar kinestetik adalah yang paling mendominasi. Dengan penerapan strategi pembelajaran ekspositori hanya 3,33\% siswa yang tuntas atau mencapai KKM. Oleh karena itu, pemilihan strategi pembelajaran harus disesuaikan dengan kondisi siswa, dalam hal ini gaya belajar. Apabila di dalam kelas terdapat keberagaman gaya belajar guru bisa menggunakan strategi pemebelajaran yang berpusat pada siswa seperti strategi pembelajaran kontekstual.

\section{Ucapan Terimakasih}

Ucapan terima kasih kepada pihak SMA Paramarta 1 Seputih Banyak yang telah memberikan kesempatan dan izin kegiatan penelitian hingga selesai.

\section{Kepustakaan}

[1] Riswanto and N. A. K. Dewi, Peningkatan Keterampilan Proses Sains Melalui Pembelajaran Berbasis Laboratorium Untuk Mewujudkan pembelajaran Berkarakter, J. Ris. dan Kaji. Pendidik. Fis., vol. 4, no. 2, pp. 60-65, 2017.

[2] Trianto, Mendesain Model Pembelajaran InovatifProgresif: Konsep, Landasan, dan Implementasinya pada Kurikulum Tingkat Satuan Pendidikan (KTSP). Jakarta: Kencana, 2010.

[3] W. Sanjaya, Strategi Pembelajaran Berorientasi Standar Proses Pendidikan, cet. 2007.

[4] H. B. Uno, Model Pembelajaran. jakarta: Bumi Aksara.

[5] Y. Riyanto, Paradigma Baru Pembelajaran. Jakarta: Kencana.

[6] S. Hatami, "Learning styles," Elt J., vol. 67, no. 4, pp. 488-490, 2012.

[7] D. Boby and H. Mike, Quantun Leraning. Terjemahan oleh Alwiyah Abdurrahman, Bandung: Kaifa.

[8] S. Windura, Be An ABsolute Genius. Jakarta: Gramedia.

[9] A. Halim, Pengaruh strategi pembelajaran dan gaya belajar terhadap hasil belajar fisika siswa SMP N 2 Secanggang Kabupaten Langkat, J. Tabularasa, vol. 9, no. 2, pp. 141-158, 2012.

[10] I. Cimermanová, The Effect of Learning Styles on Academic Achievement in Different Forms of Teaching,
Int. J. Instr., vol. 11, no. 3, pp. 219-232, 2018.

[11] C. Rose and M. J. Nicholl, Accelerated Learning for The 21st Century. Terjemahan oleh Dedy Ahimsa, Bandung: Nuansa, 22AD.

[12] J. Situmorang, Strategi Pembelajaran dan Gaya Belajar Terhadap Hasil Belajar Geografi, J. Teknol. Pendidik., vol. 6, no. 1, pp. 64-78, 2013.

[13] S. N. Aini and P. Sudira, Pengaruh strategi pembelajaran, gaya belajar, sarana praktik, dan media terhadap hasil belajar patiseri SMK se-Gerbangkertasusila, J. Pendidik. Vokasi, vol. 5, no. 1, pp. 88-102, 2015.

[14] M. L. Crawford, Teaching Contextual: Research, Rationale and Tachniques for Improving Student Motivation and Achievemen $t$ in Mathematics and Sciences. Texas: CCI Publishing, 2001.

[15] N. A. K. Dewi, N. S. Aminah, and S. Sukarmin, "Pengembangan Modul Fisika Berbasis Relating, Experiencing, Applying, Cooperating, and Transferring (React) Pada Materi Alat Optik Untuk Meningkatkan Kecerdasan Majemuk Dan Kreativitas Siswa," INKUIRI J. Pendidik. IPA, vol. 4, no. 2, pp. 47-56, 2015.

[16] A. M. Putri, Penerapan Model Pembelajaran Kontekstual Dengan Pendekatan Snowball Throwing Untuk Mengembangkan Karakter Komunikatif dan Rasa Ingin Tahu Siswa SMP, Universitas Negeri Semarang, 2013. 